\title{
GERAKAN HIJRAH DAN KONSTRUKSI EMOSI KEISLAMAN DI PERKOTAAN
}

\author{
Sahlul Fuad \\ Institut PTIQ Jakarta, Indonesia \\ Email:sahfuad@ptiq.ac.id
}

\begin{abstract}
This paper discusses the construction of Islamic Islamic emotions in urban areas as a reflection of the influence of the hijrah movement that is widespread in Indonesia. The growth of the Muslim middle class and the rapid advancement of information technology in Indonesia has become fertile ground for the increasing migration movement among millennial. The movement of hijrah is an expression of new Islamic emotions that brings together the spirit of religiosity and the lifestyle of the middle class. However, along with the increasing trend of transnational ideologies that lead to fundamentalism and radicalism movements, the migration movement has the potential to support transnational ideological movements targeting young people who are new to Islam.
\end{abstract}

Keywords: Hijrah Movement; Islamic Emotions; Urban; Ideology.

Abstrak. Paper ini membahas tentang konstruksi emosi keislaman muslim perkotaan sebagai refleksi atas pengaruh gerakan hijrah yang berkembang luas di Indonesia, khususnya di kawasan perkotaan. Pertumbuhan kelas menengah muslim dan kemajuan teknologi informasi yang pesat di Indonesia menjadi lahan yang subur bagi meningkatnya gerakan hijrah di kalangan millenial. Gerakan hijrah merupakan ekspresi emosi keislaman baru yang mempertemukan antara semangat religiusitas dan gaya hidup kelas menengah. Namun, seiring dengan meningkatnya kecenderungan ideologi transnasional yang mengarah pada gerakan fundamentalisme dan radikalisme, gerakan hijrah menjadi potensial sebagai pendukung gerakan ideologi transnasional yang menyasar para generasi muda yang baru mengenal Islam.

Keywords: Gerakan Hijrah; Emosi Keislaman; Perkotaan; Ideologi.

Permalink/DOI: https://doi.org/10.15408/mimbar.v37i1.17949 


\section{Pendahuluan}

"Gerakan Hijrah" merupakan fenomena semangat keberagamaan Islam kontemporer di Indonesia, khususnya di kawasan perkotaan, yang direpresentasikan melalui berbagai gaya hidup dan emosi keislaman yang khas. Ada beragam pandangan dalam menilai fenomena gerakan hijrah ini, antara lain ia dinilai sebagai fenomena menguatnya "revivalisme Islam" (Murkilim, 2017), "conservative turn" (Sebastian \& Nubowo, 2019), "komodifikasi agama”, "rebranding Islam”(Hoesterey \& Saat, 2017), dan lain sebagainya. Keragaman pandangan ini di antaranya dikaitkan dan seiring dengan makin derasnya arus ideologi transnasional yang tumbuh-berkembang di negeri ini. Hal ini dapat ditengarai bahwa di tengah masifnya promosi ideologi-ideologi transnasional tersebut menemukan titik temu dan saling mengisi dengan gerakan hijrah yang haus tentang keislaman.

Pertemuan antara promosi ideologi- ideologi transnasional dengan gerakan hijrah yang dilancarkan secara masif melalui media-media sosial tidak hanya mentransformasi pemahaman keislaman masyarakat, tetapi juga mengaduk-aduk emosi keislaman muslim di Indonesia. Dengan jargon-jargon tersebut, sentimen atau emosi keislaman yang berkembang saat ini menjadi diidentikan dengan ciri kelompok Gerakan Hijrah karena berdekatan dengan tokoh-tokoh kelompok- kelompok pengusung ideologi transional. Akibatnya, Gerakan Hijrah menjadi kelompok yang terlibat dalam kontestasi ideologi yang berkembang di Indonesia. Apalagi, kelompok ini merepresentasikan diri melalui berbagai praktik berkonsumsi dan berkomunikasi sebagaimana yang menjadi ciri ideologi transnasional (Hasan, 2016). Mereka juga juga mengeksprsikan tampilan emosi yang dikonstruk oleh budaya yang diusung oleh ideologi gerakan transnasional ini (Heryanto, 2015). Dalam konteks ini, paper ini akan mencoba membahas tentang konstruksi emosi keislaman muslim perkotaan sebagai refleksi atas pengaruh gerakan hijrah yang berkembang luas di Indonesia, khususnya di kawasan perkotaan. According to Kahin, through his nationalism theory, Islam does not passively absorb the impulses from the original concept of nationalism. Instead, it offered the earliest conduit for forming modern and mature nationalism for Indonesian, a channel that continues to play a significant role. The unique ideology of Islam, which is accepted by almost 90 percent of Indonesian people, has made it feasible. In addition, Kahin believes that Islam in Indonesia is tolerant, avoiding extremism and radicalism, as is frequently the case in other areas of Islam, such as in the Middle East (George Mc Turnan Kahin, 2013). (George Mc Turnan Kahin, 2013).

Untuk membahas lebih jauh tentang pengaruh gerakan hijrah terhadap konstruksi emosi keislaman muslim perkotaan ini, tulisan ini akan dibagi dalam tiga bagian. Pertama, pembahasan tentang fenomena gerakan hijrah di perkotaan. Kedua tentang konsep emosi sebagai konstruksi sosia-kultural. Dan terakhir akan mendiskusikan tentang konstruksi emosi keislaman.

\section{Gerakan Hijrah Di Perkotaan}

Gerakan hijrah merupakan salah satu fenomena gerakan kontemporer yang mendapat perhatian banyak kalangan di antara maraknya gerakan keislaman lainnya, khususnya di perkotaan. Fenomena ini makin menyedot perhatian publik manakala sejumlah selebritis papan atas turut meramaikan HijrabFest (Festival Hijrah) dengan peserta mencapai puluhan ribu, yang diselenggarkan Fam Company pada akhir 2019 lalu. Sejumlah dai ternama di kalangan millenial, seperti Abdul Somad, Adi Hidayat, Salim Fillah, Felix Siauw, dan Hanan Attaki turut mendukung kesuksesan acara tersebut. Festival Hijrah ini adalah bakal digelar sebagai agenda tahunan sejak 2018. 
Jika HijrabFest dilihat sebagai "puncak gunung es" maka gerakan hijrah di Indonesia tampaknya merupakan hasil dari perjalanan panjang yang menemukan momentumnya. Zahrin Sanni Musahadah dan Sulis Triyono mencatat bahwa masifnya gerakan hijrah dapat dilihat melalui media sosial, seperti facebook, instagram, whatsapp, youtube, dan telegram (Musahadah \& Triyono, 2019).

Meski demikian, Agnia Addini mengklaim bahwa gerakan hijrah yang telah merambah perkotaan Indonesia sejak 1980-an ini tidak lepas dari ekspansi ragama gerakan Islamisme transnasional (Addini, 2019). Sebagaimana Addini, Carter Banker juga menemukan bahwa penggerakan di balik gerakan hijrah yang berbasis di kampus-kampus Indonesia ini adalah Hizbut Tahrir Indonesia (HTI), Tarbiyah, and Salafisme. Gerakan hirjah makin membesar sejak jatuhnya Suharto pada 1998, yang ditandai dengan berakhirnya reprsi negara terhadap kelompok-kelompok dan gerakan Islam. Anggota-anggota dari gerakan ini merupakan generasi $Z$ yang tumbuh tanpa pendidikan agama yang baik. Kurangnya pendidikan agama di kalangan mahasiswa merupakan target utama dari gerakan hijrah. Umumnya mereka berasal dari kalangan kelas menengah baru, dan mereka memiliki karir yang bagus dalam pekerjaan, seperti dokter, ahli teknik, dan lain-lain.

Pada 2012 muncul gerakan Indonesia Tanpa JIL (ITJ), sebagai reaksi atas demonstrasi "Indonesia Tanpa FPI" yang diselenggarakan pada 14 Februari 2012. Gerakan ini menyebar ke berbagai daerah, khususnya perkotaan, seperti Bekasi, Solo, Nusa Tenggara Barat, dan berbagai kota besar lainnya di Indonesia. ITJ tercatat mempunyai 25 chapter se-Indonesia, baik chapter wilayah maupun lembaga. Begitu juga beragam kegiatan telah dilaksanakan untuk memberikan edukasi kepada masyarakat tentang bahayanya pemikiran Islam liberal. Bahkan gerakan ITJ ini menggelar berbagai kegiatan untuk mempromosikan ideologinya kepada masyarakat luas, mulai dari program bersepeda untuk memperingati Sumpah Pemuda, seminar pelajar, hingga penggalangan dana untuk rakyat Palestina. Bahkan ulang tahun aksi ini juga diperingati oleh komunitas- komunitas yang pernah terlibat pada tahun berikutnya dengan berbagai agenda. Pada 2017, Silatnas ITJ mengangkat Koordinator Pusat ITJ Periode 2017-2020 (Hidayatullah).

Mutasi pergerakan hijrah melalui media sosial makin masif, menurut Addini, saat munculnya "Gerakan Pemuda Hijrah" yang dipelopori Ust. Hanan Attaki pada Februari 2015. Gerakan ini memiliki tujuan mengenalkan agama kepada anak-anak muda di Kota Bandung dengan gaya fun dan friendly. Sejak itu, akun-akun media sosial dakwah makin bermunculan, seperti akun Indonesia Tanpa Pacaran pada September 2015, yang menggema ke berbagai penjuru kota seperti di Medan (Sari, Husein, \& Noviani, 2019). Begitu juga akun- akun lain, seperti Hijrah Santun, Berani Hijrah, Hirjah Cinta, dan sebagainya. Hampir komunitas-komunitas yang menggunakan label "Hijrah", dengan beragam variasinya, memiliki jaringan antar kota dan beranggotakan hingga ribuan hingga jutaan.

Gerakan 212, yang bertajuk Aksi Bela Islam pada 2 Desember 2016 yang berhasil menyedot peserta hingga jutaan orang di kawasan Monumen Nasional (Monas), merupakan representasi dari keberhasilan dan sekaligus pintu kelas menengah urban masuk dalam gerakan hijrah. Melalui blow up media yang luas, share foto-foto dan video melalui media sosial yang dilakukan para peserta dalam aksi tersebut, termasuk dengan para artis dan tokoh-tokoh publik lainnya, Gerakan 212 mendapat posisi penting di hati muslim Indonesia. Hadirnya para artis pendukung gerakan hijrah dalam gerakan 212 memperteguh representasi tersebut. 
Seiring dengan berkembangnya trend hijrah dan meningkatnya gerakan-gerakan muslim perkotaan di Indonesia, HijrabFest menemukan momentum yang lebih tegas dalam mewarnai gerakan Islam kontemporer di Indonesia. Hadirnya sekitar 40 ustaz populer di media sosial yang memberikan pengajian selama tiga hari non-stop di hadapan puluhan komunitas hijrah dari berbagai kota, sharing session artis hijrah, komunitas muslim, sampai sajian aneka produk muslim menjadikan HirjabFest sebagai ajang yang bergengsi. Perjumpaan ini merupakan arena bagi gerakan hijrah untuk membangun solidaritas dan jaringan hirjah makin kuat dan luas.

Serangkaian fenomena di atas menunjukkan bahwa gerakan hijrah merupakan salah satu bentuk gerakan sosial. Meskipun terdapat berbagai definisi tentang gerakan, namun sebagian besar didasarkan pada beberapa hal berikut, yaitu: aksi kolektif atau bersama; mengubah tujuan atau klaim yang berorientasi; beberapa tindakan kolektif ekstra atau non-institusional; beberapa tingkat organisasi; dan beberapa tingkat kesinambungan waktu.

\section{Emosi Dan Konstruksi Budaya Dalam Gerakan Sosial}

Konsepsi tentang emosi bukan bukan hanya menjadi rana kajian psikologi, tetapi juga menjadi pembahasan dalam kajian ilmu-ilmu sosial lainnya, seperti sosiologi, antropologi, dan politik. Kata emosi, seperti padanannya dalam banyak bahasa lain, mencakup banyak ekspresi, interaksi, perasaan, dan label. Istilah emosi tertentu sering diambil secara utuh dari bahasa umumnya, seperti kemarahan dan ketakutan adalah yang paling umum, padahal istilah ini mencakup berbagai jenis perasaan. Karena itu, para ilmuwan sosial membangun istilah bahasa alami ini dan juga membuat perbedaan analitik yang lebih baik di antara istilah-istilah tersebut. Meskipun para sarjana telah menyarankan agar mengembangkan subkategori yang lebih sesuai dengan berbagai jenis hal yang disebut, sebagian besar masih terus mengamati emosi dan berteori satu subkategori tersebut sambil menerapkan istilah emosi sebagai katerori alami tersebut (Jasper, 2011).

Beberapa kajian ilmu sosial tersebut mencoba menempatkan faktor sosio-kultural dalam bidang kajian emosi. Masuknya faktor sosio-kultural terhadap konsep emosi, misalnya menurut Uday Jain, menunjukkan fakta bahwa emosi tidak dimanifestasikan seseorang dalam ruang hampa, tetapi ia berada dalam situasi konkret yang terkait dengan budaya yang berlaku. Di sini mereka meletakkan budaya dalam diri individu sebagai faktor personalitasnya (Jain, 1994).

Karya-karya klasik seperti Durkheim, Marx, dan Weber juga membahas teori secara terperinci tentang peran emosi dalam kehidupan sosial. Durkheim berpendapat bahwa koeksistensi dalam lingkungan perilaku kolektif yang dikombinasikan dengan ritual yang disinkronkan dapat menghasilkan sifat- sifat yang muncul, terutama emosi. Karl Marx dalam teori keterasingan menyatakan bahwa proses emosional yang muncul ketika kapitalisme menciptakan kontradiksi antara "keberadaan" dan "esensi" manusia. Sementara tipologi tindakan sosial yang dikemukakan Weber dibedakan antara instrumental, nilai rasional, tradisional, dan afektif.

Dalam perkembangan selanjutnya, banyak juga karya ini berfokus pada pembingkaian, identitas kolektif, kode, dan narasi. Selain itu, Banyak orang yang fokus pada emosi menuntut perubahan budaya karena terlalu kognitif. Ada beberapa tesis yang menunjukkan relasi emosi dalam kajian ilmu-ilmu sosial lainnya. Averill (1980) mengajukan tesis bahwa emosi dikonstruk menurut aturan-aturan budaya. Emosi merupakan serangkaian respons sosial yang ditentukan untuk situasi yang sesuai (Armon-Jones, 1986). 
Emosi didasarkan pada informasi tentang bagaimana merasakan dan mengekspresikan dalam situasi tertentu (Heels, 1986); mereka adalah penilaian situasi berdasarkan kepercayaan dan nilai-nilai budaya (Lynch, 1990); emosi dikuatkan oleh jenis kegiatan dan hubungan di mana mereka diberlakukan (White, 1990); mereka adalah pernyataan tentang dan motivasi untuk diberlakukannya nilai-nilai budaya (Lutz, 1982); emosi adalah praktik sosial (Abu- Lughod, 1990); mereka adalah pikiran yang diwujudkan (Rosaldo, 1984); emosi adalah konstituen dari bentuk relasional (Gergen, 1990) dan peran sosial sementara (Averill, 1982). Semua konsepsi ini didasarkan pada asumsi bahwa masyarakat membentuk kehidupan emosional para anggotanya yang memanifestasikan emosi dengan cara yang dapat dipahami oleh anggota lainnya.

Kajian tentang emosi dalam gerakan sosial juga kurang mendapat perhatian (Flam \& King, 2005). Para teoritisi perilaku kolektif masa lalu lebih fokus pada dinamika emosinal pada situasi kerumunan dan perubahan sosial. Mereka tertarik pada perasaan sebagai proses manipulasi ketidaksadaran, histeria, panik, dan cenderung menginterpertasikan emosionalitas sebagai sebentuk tanda irasionalitas (Jasper, 2011). Dari telaah yang dilakukan Justin Van Ness dan Erika Summers-Effler terhadap berbagai kajian tentang emosi dan gerakan sosial, mengemuka beberapa teori terkait, yaitu mobilisasi gerakan sosial, komitmen, dan demobilisasi. Terkait dengan keterlibatan gerakan sosial yang mendapat perhatian adalah aspek kekuatan jaringan sosial dan organisasi untuk merekrut, mengaktifkan, dan komitmen partisipan.

Peran para pemimpin gerakan sosial sangat memengaruhi pada keberhasilan gerakan dan membangun emosi para anggotanya. Marshall Ganz dan Elizabeth McKenna berpendapat bahwa dinamika pemimpin adalah kunci untuk memahami gerakan sosial. Sebab melalui motivasi dan kapasitasnya untuk merekruit anggota yang lebih besar dibutuhkan kekuatan peran pemimpinnya. Kemampuan pemimpin dalam membangun narasi dapat mengartikulasikan identitas individual, kelompok, dan kebutuhan untuk bertindak (Ganz \& McKenna, 2018).

Menurut Ness dan Summers-Effler, perhatian pada proses emosional yang melibatkan identitas juga dapat menjelaskan bagaimana mengidentifikasi identitas yang dihasilkan untuk mobilisasi. Identitas dapat memberikan energi untuk memulihkan dengan penuh semangat. Melalui ritu, mereka menciptakan solidaritas bersama dan dapat menghasilkan perasaan bersama, energi emosional bagi individu, simbol kelompok, dan standar moralitas. Simbol bersama dapat terdiri dari ikon visual, katakata, ideologi, gerakan, dan representasi lainnya. Anggota menanamkan lambang-lambang ini dengan rasa kebenaran dan moralitas (Jasper, 2011).

\section{Konstruksi Emosi Keislaman Dalam Gerakan Hijrah}

Pembahasan sebelumnya tampak bahwa gerakan hijrah merupakan salah satu bentuk gerakan sosial yang memiliki jaringan luas di kalangan muslim kelas menengah di perkotaan. Sebagai gerakan sosial, ia tidak tumbuh tiba- tiba, namun memiliki akar sejarah panjang yang berkesinambungan dan saling terkait. Untuk memotret lebih mendalam bagaimana gerakan hijrah mampu mewarnai wajah Islam di Indonesia di antara kelompok-kelompok mainstream, pada bagian ini akan dibahas tentang konstruksi emosi keislaman dalam gerakan hijrah.

Islam tradisional sebagai kelompok mainstream yang tumbuh dan kembang dalam pendidikan dan budaya keagamaan yang kental memiliki karakteristik yang khas di Indonesia. Coraknya yang mampu berdialog dengan budaya-budaya lokal berhasil melahirkan budaya keislaman yang berkembang 
di kalangan kelas ekonomi bawah secara bersahaja. Islam sehari-hari yang dikembangkan oleh kelompok Islam tradisional ini, meski ada beberapa pengecualian, telah menjadikan pemandangan yang lumrah. Bagi masyarakat kebanyak tidak dinilai sebagai menonjolkan simbol-simbol keislaman dalam ruang publik secara berlebihan.

Berbeda dengan masifnya gerakan hijrah yang tumbuh kembang akhir-akhir ini, simbol- simbol keislaman dalam ruang publik tampak tampil secara memukau. Tampilnya mobil- mobil mewah dengan atribut kaligrafi Arab bertuliskan kalimat Tahlil, baju-baju dan jilbab muslimah mewah, bertebaran pesan meme dengan desain-desain unik dan menarik, dan lain-lain tiba-tiba menarik perhatian banyak orang. Mereka adalah kelas menengah ke atas yang mampu mengakses artibut-atribut keislaman yang lebih berkualitas secara estetis. Selera mereka terhadap atribut-atribut keislaman tersebut adalah produk dari konstruksi dunia yang mereka alami selama ini. Pilihan estetik adalah seperangkat pilihan etis yang membentuk gaya hidup tertentu (Bourdieu \& Nice, 2012).

Simbol-simbol keislaman yang diyakin pemeluknya memiliki kesucian, atas dasar pemahaman terhadap ajaran agama, merupakan fenomena yang tampak nyata dalam alam batin. Perasaan takut atau gembira yang didasarkan pada ajaran-ajaran agama merupakan pengalaman batin yang hanya dapat dirasakan individu aktornya. Meski simbol selalu bersifat publik, ia menyimpan makna yang dalam bagi pelakunya. Simbol-simbol keislaman adalah ekspresi batin seseorang untuk mencapai rasa kepuasan dan kepatuhannya dalam menjalankan ajaran- ajaran agama (Geertz, 1973). Untuk itu, pemilihan atau pemakaian atribut-atribut keislaman adalah ekspresi perasaan mereka dalam beragama yang dipengaruhi oleh rasionalitas sesuai dengan kelas sosial mereka.

Keberhasilan gerakan hirjah untuk menampilkan dan mendemonstrasikan simbol- simbol keislaman yang bercita rasa estetis tinggi, mampu menarik perhatian para muslim urban yang belum pernah mereka temukan. Mereka menemukan identitasnya sebagai muslim dan sekaligus sebagai kelas menengah perkotaan. Dan identitas tersebut makin menguat seiring dengan pelayanan-pelayanan yang diberikan team kreator untuk memproduksi pemahaman-pemahaman baru, baik berupa aksesoris maupun pengetahuan, yang tidak mereka peroleh dari bangku pendidikan formal mereka.

Mereka rela mengeluarkan dana yang besar untuk memenuhi kebutuhan gerakan hijrah. Dalam konferensi pers yang digelar oleh panitia HijrabFest, misalnya, disebutkan mereka mampu mengumpulkan dana sebesar Rp 28 miliar. Tiket peserta untuk mengikuti kegiatan tersebut sebesar Rp 80.000,00. Belum lagi sumbangan-sumbangan yang berwujud iklan dan lain sebagainya. Mereka menyatakan bahwa di antara target yang diharapkan dari HijrahFest adalah mengumpulkan lebih banyak ukhwah dan business mathcing. Dengan dana yang besar tersebut, akan dijadikan sebagai energi dakwah ke depannya.

Fenomena ini, selain dapat dilihat sebagai meningkatnya kesadaran filantraopi keislaman, juga dapat dilihat sebagai sinyal terjadinya komodifikasi identitas keislaman yang kuat dalam gerakan hijrah. Peluang ekonomi bagi industri-industri tertentu, seperti pakaian, makanan, broad(pod)cast, film, dan lain-lain dengan pendekatan identitas keislaman menjadi alat untuk mengikat pelanggan sebagai konsumen. Iklan-iklan pakaian muslimah memenuhi kolom status komentar di media sosial.

Di saat yang bersamaan, keberadaan gerakan hijarah yang menggejala di berbagai kota muncul banyak temuan penelitian tentang meningkatnya kecenderungan ideologi transnasional yang mengarah 
pada gerakan fundamentalisme dan radikalisme. Hal ini menimbulkan beberapa kekhawatiran yang mengarah pada dukungan yang lebih besar terhadap harmoni keragaman keagamaan di Indonesia. Sentimen keislaman dengan cara memunculkan perasaan kebencian terhadap kelompok-kelompok yang sesuai dengan karakteristik ideologi yang diusung ideologi transnasional mewabah di media-media sosial secara masif. Jaringan media sosial menjadi ruang konstestasi dan ketegangan berbagai kelompok idologi yang beragam. Di ruang media tersebut identitas ideologi-ideologi tersebut menjadi menjadi kabur, tidak lagi bisa dipisahkan antara ideologi Salafisme Wahabi, Ikhwanul Muslimin, maupun gerakan hijrah. Mereka terselubungi oleh identitas keislaman yang bergerak secara masif. Apalagi, hal ini masuk dalam ruang konstestasi politik, seperti pemilihan kepala daerah dan presiden wakil presiden.

Fenomena "perang komentar" yang mengumbar kebencian di media sosial merupakan ruang terbuka yang potensial untuk menularkan emosi identitas. Penularan emosi atau sentimen identitas keislaman potensial menjadi alat untuk merawat loyalitas para pendukung gerakan ideologi transnasional dengan sasaran para generasi muda yang baru mengenal Islam. Ideologi-ideologi transnasional, melalui agensi-agensinya, tampak melakukan serangan-serangan yang fundamental terhadap kecenderungan yang diusung oleh kelompok-kelompok ideologi maistream yang telah lama berkembang di Indonesia selama ini, baik dalam bidang ajaran pokok maupun bidang-bidang sosioekonomi dan politik, sebagai "tidak Islam". Mereka mendekonstruksi keislaman yang telah lama berkembang di Indonesia dan mendoktrinkan ajaran Islam yang "paling benar" sebagai konstruksi keislaman yang lebih murni dan benar.

\section{Penutup}

Gerakan hijrah merupakan fenomena wajah Islam kontemporer mampu mengubah wajah Islam di Indonesia. Pertumbuhan kelas menengah muslim dan kemajuan teknologi informasi yang pesat di Indonesia menjadi lahan yang subur bagi meningkatnya gerakan hijrah di kalangan millenial. Gerakan hijrah ekspresi emosi keislaman baru yang mempertemukan antara semangat religiusitas dan gaya hidup kelas menengah baru. Namun, seiring dengan meningkatnya kecenderungan ideologi transnasional yang mengarah pada gerakan fundamentalisme dan radikalisme, gerakan hijrah menjadi potensial sebagai pendukung gerakan ideologi transnasional yang menyasar para generasi muda yang baru mengenal Islam.

\section{Daftar Pustaka}

1 Tahun Indonesia Tanpa JIL Bekasi” Dakwatuna, 2 Maret 2013. https://www.dakwatuna.com/2013/04/ 02/30338/1-tahun-indonesia-tanpa-jilbekasi/\#axzz2mDwVDTSX

Agnia Addini, Fenomena Gerakan Hijrah di Kalangan Pemuda Muslim Sebagai Mode Sosial, (Journal of Islamic Civilization. Volume 1, Nomor 2, Oktober 2019), h. 109-118Alfarizi, Salman. (2012). Mohammad Hatta: Biografi Singkat 1902-1980. Yogyakarta: Garasi.

Ariel Heryanto, Identitas dan Kenikmatan: Politik Budaya Layar Indonesia, (Jakarta: KPG, 2015) 
Carter Banker "The Changing Face of Indonesian Islam” The Diplomat.com terbit 24 Desember 2019

https://thediplomat.com/2019/12/the- changing-face-of-indonesian-islam/

Clifford Geertz, The Interpretation of Cultures: Selected Essays, New York: Basic Book, 1973

David A. Snow, Sarah A. Soule, Hanspeter Kriesi, dan Holly J. McCammon, The Wiley Blackwell Companion to Social Movements John Wiley \& Sons, 2019

Ditha Prasanti dan Sri Seti Indriani, Konstruksi Makna Hijrah Bagi Anggota Komunitas Let's Hijrah dalam Media Sosial Line, (Jurnal Al-Izzah Volume 14, Nomor 1 Mei, 2019), h. 106-119

https://www.hidayatullah.com/berita/nasional/read/2017/08/07/121056/akmal-sjafril-resmi-jadikoordinator-pusat- indonesia-tanpa-jil.html

James Bourk Hoesterey, Rebranding Islam: Piety, Prosperity, and a Self-Help Guru. (Stanford University Press, 2016)

James M. Jasper, Emotions and Social Movements: Twenty Years of Theory and Research, (Annu. Rev. Sociol. 37: 2011), h. 285-303 Doi:10.1146/annurev-soc-081309-150015

James M. Jasper, Emotions and Social Movements: Twenty Years of Theory and Research, (Annu. Rev. Sociol. 37: 2011), h. 285-303 Doi:10.1146/annurev-soc-081309-150015

Justin Van Ness dan Erika Summers-Effler, "Emotions in Social Movements", dalam David A. Snow Sarah A. Soule Hanspeter Kriesi Holly J. McCammon, The Wiley Blackwell Companion to Social Movements John Wiley \& Sons, 2019

Leonard C. Sebastian, Andar Nubowo, The 'Conservative Turn' in Indonesian Islam: Implications for the 2019 Presidential Elections, Asie.Visions, No. 106, March 2019

Lihat Piere Bourdieu, Distincion: A Social Critique of the Judgement of Taste, (translated by Richard Nice), Cambridge: Harvard University Press, 1984

Marshall Ganz dan Elizabeth McKenna, "Bringing Leadership Back In”, dalam David A. Snow Sarah A. Soule Hanspeter Kriesi Holly J. McCammon, The Wiley Blackwell Companion to Social Movements John Wiley \& Sons, 2019

Murkilim, New Revivalisme Islam, (Nuansa: Vol.X, No. 2, Desember 2017), h. 164-169

Noorhaidi Hasan, "Islam di Kota-Kota Menengah Indonesia: Kelas Menengah, Gaya Hidup, dan Demokrasi”, dalam Garry van Klinken dan Ward Berenschot, In Search of Middle Indonesia: Kelas Menengah di Kota-Kota Menengah, (Jakarta: KITLV-Jakarta dan YOI, 2016), h. 215-245

Trie Yunita SARI, Hijrah and Islamic Movement in Cyberspace A Social Movement Study of AntiDating Movement \#IndonesiaTanpaPacaran, Yogyakarta: Sekolah Pascasarjana UGM, 2019

Uday Jain, Socio-Cultural Construction of Emotions, New Delhi: Sage Publication, 1994 
MIMBAR Agama Budaya, 37 (1), 2020

Zahrina Sanni Musahadah dan Sulis Triyono, Fenomena Hijrah di Indonesia: Konten Peruasif dalam Instagram (RETORIKA: Jurnal Bahasa, Sastra, dan Pengajarannya, Volume 12, Nomor 2 Agustus 2019), h.117-127 